\title{
Development of Forest Typology in Russia
}

\author{
N. S. Ivanova and E. S. Zolotova
}

Botanical Garden of Ural Branch RAS, $8^{\text {th }}$ March Str., 202, Yekaterinburg (620 144), Russia

\section{Article History}

Manuscript No. AR742

Received in $5^{\text {th }}$ May, 2014

Received in revised form $16^{\text {th }}$ May, 2014

Accepted in final form $28^{\text {th }}$ May, 2014

\section{Correspondence to}

*E-mail: i.n.s@bk.ru

\section{Keywords}

Forest typology, Russia

\begin{abstract}
Forest typology holds the central position in modern forestry. We give an overview of research on forest typology in Russia. Forest typology in Russia actively developed and improved with respect to requests forestry throughout the entire period of its existence. It remains the necessary basis for preserving the biodiversity of land ecosystems and ensuring sustainable forest management amid the growing anthropogenic impact and climate change. The birth of scientific forest typology is associated with the name of G.F. Morozov. A biogeocoenotic approach to forest classification was offered by V.N. Sukachev. V.N. Sukachev developed classifications for boreal forests which had been little affected by economic activity. The biogeocoenotic approach proved effective there. However, when literally applied to commercial forests, the biogeocoenotic approach sometimes failed to deliver satisfying results. The exponential shrinkage of natural forests and the increasing share of dynamic secondary growth brought about the need to reflect the time-related forest changes in classifications. The origins of the genetic approach can be found in the writings of G.F. Morozov. The first satisfactory geo-genetic forest classification was built by B.A. Ivashkevich. B.P. Kolesnikov provided the theoretical grounding and main postulates for the approach. According to B.P. Kolesnikov, a geographical and genetic classification means a classification based on the forest origin and evolution patterns which takes account of all the forest ecosystem stages and can be used to predict their future changes. Currently forest typology develops as an interdisciplinary science. It integrates forestry, geobotanics, forest taxation, soil sciences, biogeography, geology, and landscape ecology. A new methodology is being developed. It is a synthesis of forest ecology and synergetic. It uncovers new reserves for the forest science development.
\end{abstract}

\section{Introduction}

The development of a general theory of structural and functional organization of natural ecosystems is an important task of modern science, and is directly linked to ecosystems classification. Forest typology is a reliable basis to develop new theoretical assumptions and classification methods for different countries and continents (Dyrenkov, 1989). Forest typology holds the central position in modern forestry (Smologonov, 2006). For over 110 years since its appearance the science of forest types has generated heated debate (Sukachev, Zonn, 1961; Rysin, 2009). The primary task of the science is to theorize ecosystems organization locally, regionally and globally, as a basis to manage environment conditions and its renewable resources (Dyrenkov, 1989).

The concept of forest types was born long ago, well before the theory of ecosystems and biogeocoenoses (Melekhov, 1976).
It appeared as a popular observation in the late $19^{\text {th }}$ - early $20^{\text {th }}$ centuries. "Like soil, like forest," peasants used to say. The popular idea of the differences in the forest's nature was then picked up by foresters and adopted by specialized literature.

\section{G.F. Morozov's Theory of Forest Types}

The birth of scientific forest typology is associated with the name of G.F. Morozov (1904, 1931). He defined a forest type as a classificatory forestry unit representing the total of stands under similar terrain conditions with similar regeneration (Morozov, 1931). This term referred to a certain climate area and terrain type, and certain soil conditions. Forest type was the lowest classificatory unit. The higher levels included woodland types, sub-areas and areas, sub-zones and zones. Morozov associated woodland types with terrain types. Thus, he built on the assumption that a forest is organized geographically, and all types of economic operations there are subject to the 
'geographical element'. This was summarized in a well-known saying 'forest is a geographical phenomenon, and forestry is a geographical trade'. The scientist made an attempt at outlining a system of forest classification units. It was connected with the need in forestry zoning of the country (forest type - woodland type - forestry area - forestry zone) and development of geographical forestry systems.

Later in his professional life, Morozov developed a much wider understanding of forest types. He listed the following main factors determining forest types:

a. Timber species characteristics

b. Geographical environment: climate, soil, terrain

c. Biosocial relationships: between a forest's plants, between plants and environment, between plants and fauna

d. Historico-geographical factors

e. Anthropogenic factor

Considering the matter of successions, Morozov formulated the notion that a forest is a "historical phenomenon", emphasizing the dynamism of all the events there. That he pointed out should be taken into account in forest classification. A decade later, B.A. Ivashkevich $(1915,1933)$ used this idea for development a geo-genetic classification of forest types (Kolesnikov, 1970).

\section{B. N. Sukachev's Theory of Forest Types}

A biogeocoenotic approach to forest classification was offered by V.N. Sukachev (1947). A forest type is the elementary (lowest-level) classificatory unit of forest cover. Forest type unifies plots (separate forest ecosystems) homogenous in the stand composition, characteristics of other storeys, fauna, site characteristics (climate, soil, hydrology), relationships between plants and environment, regeneration, and direction of successions. It then follows that forests of the same type require the same forestry activities (Sukachev, Zonn, 1961).

Forest classification principles were built upon the assumption that each formation within a climatic zone must be supplied with a soil-plant community diagram. Forest type groups are bound to soil conditions. Each group comprises of forest types. One type considered basic, the most typical of the group. The other types in the group are adjacent. That gives us soil-plant community series. Each series represents the change of direct environment factors: humidity, soil richness, etc. The name of a forest type is determined by the prevalent timber species and one other characteristic feature, e.g. the dominating grass or moss. The name is a pure convention. Soil-plant community series reveal, if only hypothetically, the direction of successions.

V. N. Sukachev developed classifications for boreal forests which had been little affected by economic activity at the time.
The biogeocoenotic approach proved effective there. Moreover, it allowed to eliminate of some differences between the then existing forest typology schools. However, when literally applied to commercial forests, the biogeocoenotic approach sometimes failed to deliver satisfying results.

\section{Pogrebnyak's Theory of Forest Typology}

Environmental forestry approach to forest classification was developed by P.S. Pogrebnyak (Pogrebnyak, 1955). He built a practical grid of soil habitats - edatopes - taking account of the soil humidity and fertility. The grid consisted of 6 moisture grades and 4 fertility grades, using vegetation as the indicator. On the edaphic grid the natural areas of indicator plants and timber species can be shown. The notion of soil fertility has no exact content. Edatopes cannot be objectively defined, let alone measured.

P.S. Pogrebnyak refers to types of growing conditions and some reference (primary) types, instead of actual forests. The classification fails to make allowance for area geography or climate zones. Nevertheless, with all the faults the classification has become standard, especially in forest-steppe areas of Russia, Ukraine and Belarus.

\section{Geo-genetic (Geodynamical) Typology of Forest}

The exponential shrinkage of natural forests and the increasing share of dynamic secondary vegetation brought about the need to reflect the time-related forest changes in classifications.

The origins of the genetic approach can be found in the writings of G.F. Morozov (1904, 1931). Well-known are the works of V.N. Sukachev (1944) on endogenous and exogenous regenerations, successions and demutations. The first satisfactory geo-genetic forest classification was built by B.A. Ivashkevich $(1915,1933)$. He regarded a forest type as a union of many stand types which represent links of a long chain of metamorphoses under particular growing conditions. According to B.A. Ivashkevich, a forest type is characterized by growing conditions, a dominating tree species and individual features of the forest development (Ivashkevich, 1933). B.P. Kolesnikov provided the theoretical grounding and main postulates for the approach (1956). Taking from the ideas of G.F. Morozov, V.N. Sukachev, and from the concept of dynamism introduced to forest typology by B.A. Ivashkevich he developed a sophisticated theory which soon attracted many supporters in Russia and her neighboring states.

According to B.P. Kolesnikov, a geographical and genetic classification means a classification based on the forest origin and evolution patterns which takes account of all the forest ecosystem stages and can be used to predict their future changes 
(Kolesnikov, 1958). A forest type-the basic classification unit-refers to all forests (ecosystems) sharing a certain stage of regeneration or age succession, and together forming succession series which reflect the process of forest formation, regeneration and succession. Such series of elementary biogeocoenoses ("forest types" according to V.N. Sukachev, or "tree stratum types" according to B.P. Kolesnikov) are unified by more stable parameters or features characteristic of certain forest areas. B.P. Kolesnikov lists the following parameters: the dominant tree species and associated species, the land form and dominant species yield (Kolesnikov, 1961).

The geographical principle formulated by G.F. Morozov is to be relied upon when building a geo-genetic classification. Practical typology schemes must take account of the particularities of actual local conditions. They must be based on universal principles and at the same time be area-specific (Kolesnikov, 1970). A relief position is the leading characteristic in identifying the type of forest site, accompanied by hydrological regime and soil covering. The full characteristics of taxons are represented in classification tables. Taxonomic units of forest cover are always given with a site type index - a three-digit number defining the position of an area in space, its ecological address. In genetic classification, vegetation of subordinate layers plays a supplementary part while still being an important indicator of site conditions. A forest type name comprises of the traditional binary name supplemented by a relief feature and a three-digit index of site conditions. This allows for separate typology and mathematic analysis of forest types which have counterparts in different altitudinal belts and subzones (Smologonov, 1998).

A typological classification must reflect two kinds of changes: differentiation of site conditions and similar differentiation of forest growing in the same site conditions. These classifications are interrelated (Smologonov, 1998). For full account of geographical principle an alphanumeric notation system was invented. It attributes a forest type to a certain zone, subzone, province, altitudinal belt, edaphic and hydrologic complex of site conditions of various levels (class, group, or type). Unlike ecologic and floristic classification, genetic typology provides an exact "address" (geographical and ecotopic) for each forest type. The symbol system is adapted for computer processing; a researcher can single out and systemize data for any combination of taxons, including combinations from any hierarchical tiers.

Genetic classification schemes use the concept of altitudinal, zonal/subzonal, orographic, geomorphic, ecologic, and phytocoenotic counterparts. This solves a major problem of forest typology - grasping environment-specific features of the universal forest formation process. Classification and studying of forest cover based on genetic typology lay the ground for the development of forest formation management systems (Smologonov, 1998). Forest types as regarded by B.P. Kolesnikov are close to development types offered by Aichinger (Aichinger, 1967, 1973) and Leibundgut (Leibundgut, 1978, 1982).

Particular rational systems of forestry measures developed to forest types (or groups). Timely application of the latter can achieve the potential productivity of forests, and enables management of the forest formation process (Kolesnikov, 1974). Thus, genetic approach to forest classification carries a tool for predicting the future of forests and forest resources, for modeling forests of the future (Kolesnikov, 1974).

I.S. Melekhov used the base of geographical and genetic classification to develop a dynamic classification when studying cut-over and burned areas in 1959. It studies changes of forests caused by anthropogenic factors in the form of cuttings, drainings, fires, etc. (Melekhov, 1976).

\section{Contemporary Forest Typology in Russia}

Today's growing scale of economic, environmental and social conditions, recognition of forests' environmental role in biosphere changes, and the necessity to adhere to sustainable growth of regions have generated urgent need in further development of geo-genetic forest typology. It has the potential to serve a solid base for sustainable forest utilization, maintaining and recovery of vital nature resources. Forest typology develops as an interdisciplinary science. It integrates forestry, geobotanics, forest taxation, soil sciences, biogeography, geology, and landscape ecology.

Many modern modifications of the biogeocoenotic approach to forest classifications begin to reflect time-related changes of forest biogeocoenoses and natural conditions. This places them close to geo-genetic typology (Smologonov, 1990).

Genetic typology continues to improve. Based on it are regional classifications for many regions of Russia. Studies of E.P. Smologonov (1990), S.A. Dyrenkov (1989), S.N. Sannikov (1992, 1997, 2009), E.M. Filroze (1983), V.F. Tsvetkov (2009), V.N. Sedykh (2009), N.G. Ulanova (2007) have provided a solid base for the development of approached and methods of quantitative modeling of forest vegetation successtions.

The geo-genetic classification of South Urals forests was developed by E.M. Filrose (1983), G.V. Andreyev (1998) and N.S. Ivanova $(2000,2012)$. N.S. Ivanova's long-term research in the low hills of South Urals yielded quantitative data on forest succession dynamics after clear fellings. The scientist analyzed conjugacy of dynamics in forest layers and individual species in the succession series (Ivanova, 2000, 2012; Ivanova, 
2014). It was found, that succession dynamic trend are not uniform for the stand or subordinate layers. Within a single natural forest, a whole range of alternative succession series are formed - spruce, fir, birch, and aspen forests (short-term, longterm, and stable-term secondary) (Figure 1). The dynamics of the stand and subordinate layers differ in the succession series, with the differences remaining for a considerable time period (Ivanova, 2012).

B.P. Kolesnikov and his colleagues (Kolesnikov et al., 1973) published a fundamental work on typology of the Sverdlovsk region forests which is still used both for scientific purposes and in forestry in the region. However, differences in the composition of plants and soils in different forest types, especially in sub-mountain and mountain areas remained little studied until very recently. This lacuna has been filled by E.S. Zolotova and N.S. Ivanova (Ivanova, Zolotova, 2013a, 2013b) who carried out a complex research of the characteristics of plants and soils in 12 forest types and 11 types of cuttings in hills and submountains of the Zauralye province (Mid-Urals). A database was created with data on plant structure and physical and chemical characteristics of natural forests and clear fellings within a unified topo-ecological profile. The scientists have found that each forest type and cutting type has its unique vegetation structure and dynamics, as well as unique patterns

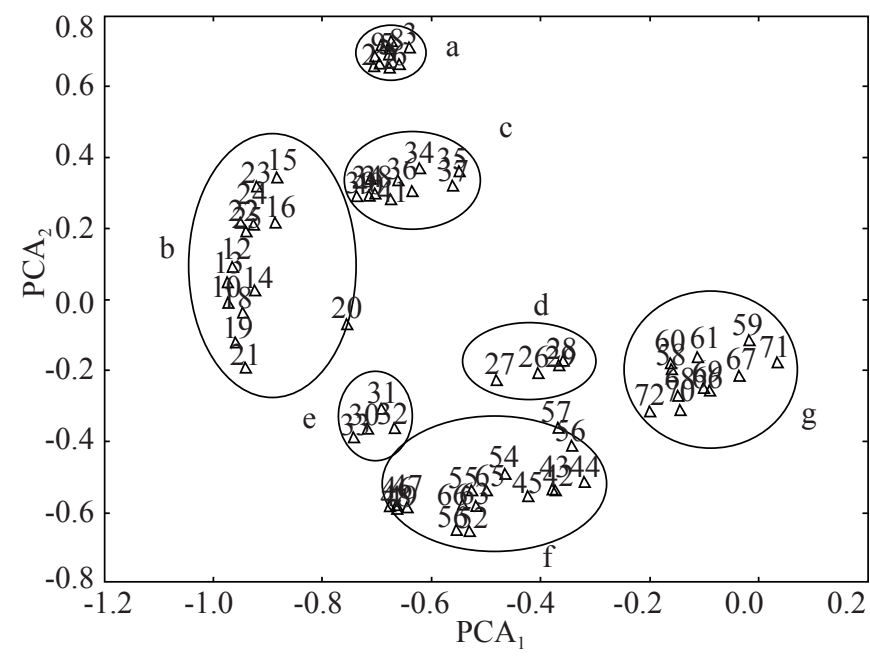

a: natural spruce forests; b: after-cutting spruce and fir forests; c: short-term secondary 60-120-year-old birch forests; d: short-term secondary 5-20-year-old birch forests; e: short-term secondary 30-40-year-old birch forests; 1: long-term secondary 5-100-year-old birch forests; g: stable-term secondary 5-100year-old aspen forests

Figure 1: Differentiation of forest vegetation (in PCA axes) after clear-cuttings in the ecotope (lower parts of smooth drained slopes with deep brown mountain forest soils) in the Southern Ural mountains of soil evolution within soil profiles (Zolotova, 2013). Using cluster analysis (Figure 2) it was found that based on the physical and chemical characteristics of their soil, horizons $\mathrm{BC}$ can be united by their succession status (forest - cutting) into compact clusters, and horizons A1 by their forest types into loose clusters. (Zolotova, 2013).

Currently, a new methodology is being developed - a synthesis of geo-genetic forest typology and synergetics. It uncovers new reserves for the forest science development (Ivanova et al., 2011, Ivanova et al., 2013). Thus, for example, the use of systems of dependent differential equations allowed to obtain quantitative characterization of forest succession dynamics. The scientists identified dynamic parameters of ecosystems (typical dynamic periods, and time needed for a full recovery of initial structure) as well as the character and degree of interdependence between individual subsystems. They also estimated the sustainability of ecosystems development and make predictions (Ivanova, 2014; Ivanova et al., 2013). The complex research of the South Urals forest structure and dynamics has allowed the researchers to build a mathematic model of the forest formation on felling sites and leverage the synergy of mathematic catastrophism and forest ecology to quantitatively predict forest state and dynamics. Objective quantitative methods have been developed for evaluating stability of successions, enabling substantiated forecasting of the state of objects described (Ivanova, Zolotova, 2013b).

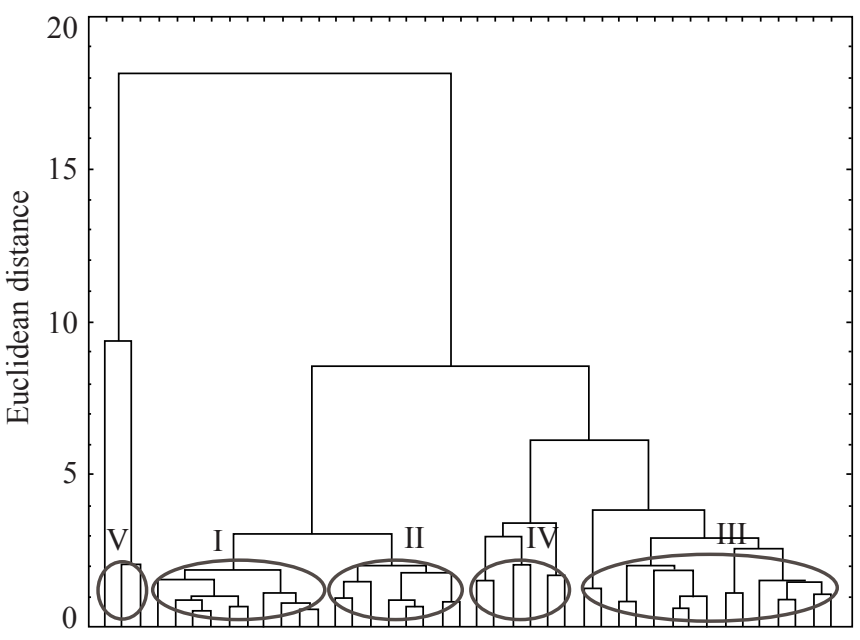

I and II clusters: horizons BC of soils of the cuttings and forests regardless of typological affiliation; III: the horizons A1 of soil of forests and cutting of smallgrassy and grassy forest types; IV: the mixed cluster, mainly the horizons BC of soils of cuttings of variousgrassy and tallgrassy forest types

Figure 2: Cluster analysis of the physical and chemical properties of the horizons A1 and BC of the soils of the conditional indigenous forests and cuttings in the Middle Urals 


\section{Conclusion}

Thus, forest typology in Russia actively developed and improved with respect to requests forestry throughout the entire period of its existence. It remains the necessary basis for preserving the biodiversity of land ecosystems and ensuring sustainable forest management amid the growing anthropogenic impact and climate change.

\section{References}

Aichinger, E., 1967. Pflanzen als forstlichen Standortszeiger. Wien, 367.

Aichinger, E., 1973. Pflanzensoziologie und ihre Auswertung in der Forstwirtschaft der Ostalpen. Carinthia II, 163/83, 43-80.

Andreev, G.V., 1998. Analysis of the Typological Structure of the Forest Lands within the Southern Ural Province of South Taiga and Mixed Forests. Contemporary Issues of the Population, Historical and Applied Ecology: Conference Materials. Ekaterinburg: Ekaterinburg Publishing House, 231-232.

Dyrenkov, S.A., 1989. To the creation of land ecosystem classification: summarizing the cross-disciplinary approach. Dynamic forest typology (Dinamicheskaya tipologiya lesa). Moscow: Agropromizdat, 4-14.

Filroze, E.M., 1983. The scheme of genetic classification of the South Urals forests. Geo-ecologic and genetic principles of forest science (Ekologo-geograficheskiye I geneticheskiye prontsipy izucheniya lesov). Sverdlovsk: UNTs AN SSSR (Student Research Center of USSR AS), 53-59.

Ivanova, N.S., 2000. Classification methods of the Southern Urals mountain forests, Forestry (Lesovedenie). 4, 1621.

Ivanova, N.S., 2012. Forests types of the Western low mountains of the Southern Urals. News of the Samara scientific center of the Russian Academy of Sciences (Izvestiya Samarskogo nauchnogo tsentra RAN).1, 1020-1023.

Ivanova, N.S., 2014. Recovery of Tree Stand after ClearCutting in the Ural Mountains. International Journal of Bio-Resource and Stress Management. 5(1), 090-092

Ivanova, N.S., 2014. Studio di coniugio dinamiche di eta riduttive dello stand e gli strati subordinati in breviderivati betulla Urali meridionali. Italian Science Review. 1(10), 218-221. Available from: http://www.ias-journal.org/ archive/2014/january/IvanovaNS.pdf.

Ivanova, N.S., Bystraj, G.P., Ohotnikov, S.A., Zolotova, E.S., 2011. Model of forests age-restoration in the Zauralsky hilly piedmont province. Modern problems of education and science (Sovremennye problemy nauki i obrazovaniya). 4. Available from www.scienceeducation.ru/98-4754

Ivanova, N.S., Zolotova, E.S., 2013a. Biodiversity of the natural forests in the Zauralsky hilly piedmont province. Modern problems of education and science (Sovremenniye problemy nauki i obrazovanija). 1. Available from http:// www.science-education.ru/107-8563.

Ivanova, N.S., Zolotova, E.S., 2013b. Model of forest restoration. Population Dynamics: Analysis, Modelling, Forecast. 2, 50-60.

Ivanova, N.S., Zolotova, E.S., Petrova, I.V., 2013. Nuovo approccio interdisciplinare allo studio degli ecosistemiforestali. Italian Science Review. 9, 97-100. Available from: http://www.ias-journal.org/archive/2013/ december/Ivanova-Zolotova.pdf

Ivashkevich, B.A., 1915. Manchzhursky, Description of Eastern Forest Concession and Operations Plan of Chinese Eastern Railway (Opisaniye Vostochnoy lesnoy kontsessii KVZhD i plan hozyaystva na ney). Harbin.1, 503.

Ivashkevich, B.A., 1933. Far East Forests and their industrial future. Moscow, Khabarovsk: OGIZ, Dalgiz, 169.

Kolesnikov, B.P., 1956. Cedar Forests of Far East, Moscow, Leningrad: Publishing office of AN USSR (Izdatelstvo AN SSSR), 264.

Kolesnikov, B.P., 1958. The state of Soviet forest typology and issues of genetic classification of forest types. Izvestiya of SO AN SSSR. 2, 109-122.

Kolesnikov, B.P., 1961. Genetic classification of forest types and its problems in the Urals, Issues of Plant Classification (Voprosy klassifikatsii rastitelnosti). Sverdlovsk, 47-59.

Kolesnikov, B.P., 1970. G.F. Morozov-pioneer of silvology and основоположник лесоведения и theoretical forestry. Forest formation processes in the Urals (Lesoobrazovatelniye protsessy na Urale), collected works of Institute of Plant and Animal Ecology. Sverdlovsk. 67, 5-14.

Kolesnikov, B.P., 1974. Genetic phase in forest typology and its tasks. Sylvology (Lesovedeniye). 2, 3-20.

Leibundgut, H., 1978. Uber die Dynamik europaischer. H. Leibundgut. Urwalder. Allg. Forst. Z. 33, 686-690.

Leibundgut, H., 1982. Europaischer Walder der Bergstufe. H. Leibundgut. Bern: Haupt, 254.

Melekhov, I.S., 1976. Forest Typology. Moscow: Lesnaya Promyshlennost, 73.

Morozov, G.F., 1904. On types of plants and their purpose in forest management. Lesnoy Zhurnal. 1, 14-94.

Morozov, G.F., 1931. The theory of forest stand types. Moscow, Leningrad: Selkolkhozgiz, 421. 
Pogrebnyak, P.S., 1955. The basics of forest typology. Kiev: Publishing office of Academy of Sciences of Ukraine SSR, 452.

Rysin, L.P., 2009. Is there a future for forest typology in Russia? Lesnyie resursy tayozhnoy zony Rossii: problem prirodopolzovaniya I lesovosstanovleniya: Materials of all-Russia science conference with international participation. Petrozavodsk: KarNTs RAN, 8-10.

Sannikov, S.N., 1992. Ecology and geography of natural regeneration of the common pine. Moscow: Nauka, 264.

Sannikov, S.N., 1997. Natural regeneration of pine on cutover and burn lands and ways of its facilitation. Priroda I lesnoye hozyaystvo. Ekaterinburg: UrO RAN, 23-26.

Sannikov, S.N., 2009. Divergence, convergence and succession of forest biocoenosis structure. Geneticheskaya tipologiya, dinamika I geografiya lesov Rossii, Ekaterinburg: UrO RAN, 56-61.

Sedykh, V.N., 2009. Age dynamics of dark conifers of Western Siberia. Geneticheskaya tipologiya, dinamika I geografiya lesov Rossii. Ekaterinburg: UrO RAN, 90-93.

Smologonov, E.P., 1990. Geo-ecological differentiation and dynamics of conifers of the Urals and Western Siberia plains (ecological and forestry basis of better management), Sverdlovsk: UrO AN SSSR, 288.

Smologonov, E.P., 1998. Main provisions of genetic approach in building forest type classifications. Ekologiya 4, 256261.
Smologonov, E.P., 2006. Forest typology in the Urals. Forestry science in the Urals: A Monograph (Lesovodstvennaya nauka na Urale: Monografiya). Ekaterinburg: Ural Forestry Engineering University, 125-140.

Sukachev, V.N., 1944. On the principles of genetic classifications in biogeocoenosis theory. Reports of USSR AS (Doklady AN SSSR) 45 (5), 5-17.

Sukachev, V.N., 1947. Fundamentals of theory of biegeocoenoses. Collection of works in commemoration of 30-th anniversary of Great October socialist revolution (Yubileynyi sbornik posvyashchonnyi 30-letiyu Velikoy Oktyabrskoy sotsialisticheskoy revolyutsii). MoscowLeningrad. 2, 283-304.

Sukachev, V.N., Zonn, S.V., 1961. Methodology instructions to studying forest types. Moscow: Publishing office of USSR AS, 143.

Tsvetkov, V.F., 2009. Types of planted vegetation as representative series of forest dynamics. Genetic typology, dynamics and geography of Russia's forests (Geneticheskaya tipologiya, dinamika i geografiya lesov Rossii). Ekaterinburg: UrO RAN, 69-71.

Zolotova, E.S., 2013. Typological features of vegetation and soils in Zauralsky hilly piedmont province: dissertation of candidate of biology: 06.03.02, Zolotova Ekaterina. Ekaterinburg, 208. 